\title{
Kinetic Studies of the Oxidation of L-Ascorbic Acid by Tris(Oxalate)Cobaltate in the Presence of CDTA Metal Ion Complexes
}

\author{
Horacio D. Moya ${ }^{a}$ and Nina Coichev ${ }^{*, b}$ \\ ${ }^{a}$ Faculdade de Medicina da Fundação do ABC, FMABC, CP 106, 09060-650 Santo André - SP, Brazil \\ ${ }^{b}$ Instituto de Química, Universidade de São Paulo, CP 26.077 05599-970 São Paulo - SP, Brazil
}

\begin{abstract}
Realizaram-se estudos cinéticos envolvendo a reação de redução de tris(oxalato)cobaltato por L-ácido ascórbico, em diferentes valores de $\mathrm{pH}$. A variação da concentração do complexo de $\mathrm{Co}$ (III) foi acompanhada pela absorbância em $600 \mathrm{~nm}$, em condições de pseudo-primeira ordem: $\left[\mathrm{H}_{2} \mathrm{~A}\right]=3,0 \times 10^{-2} \mathrm{~mol} \mathrm{~L}^{-1},\left[\mathrm{Co}\left(\mathrm{C}_{2} \mathrm{O}_{4}\right)_{3}\right]^{3-}=3,0 \times 10^{-3} \mathrm{~mol} \mathrm{~L}^{-1}$, na presença de CDTA $(3,0$ x $\left.10^{-3} \mathrm{~mol} \mathrm{~L}^{-1}\right)$, em $\mathrm{I}=1,0 \mathrm{~mol} \mathrm{~L}^{-1}(\mathrm{NaCl})$ e a $25,0 \pm 0,1{ }^{\circ} \mathrm{C}$. Foram investigadas as atividades catalíticas dos complexos de CDTA com Fe(III), Ni(II), Cu(II), Cr(III) e Mn(II). Para Fe(III)/ CDTA, o melhor catalisador, os valores de constantes de velocidade observada de pseudoprimeira ordem foram proporcionais à concentração de ferro (1-10) x $10^{-5} \mathrm{~mol} \mathrm{~L}^{-1}$.
\end{abstract}

It was investigated the kinetic of the reduction reaction of tris(oxalate)cobaltate by L-ascorbic acid, $\mathrm{H}_{2} \mathrm{~A}$, at different acidity. The $\mathrm{Co}(\mathrm{III})$ complex was monitored at $600 \mathrm{~nm}$, under pseudofirst-order conditions: $\left[\mathrm{H}_{2} \mathrm{~A}\right]=3.0 \times 10^{-2} \mathrm{~mol} \mathrm{~L}^{-1},\left[\mathrm{Co}\left(\mathrm{C}_{2} \mathrm{O}_{4}\right)_{3}\right]^{3-}=3.0 \times 10^{-3} \mathrm{~mol} \mathrm{~L}^{-1}$, in the presence of CDTA $\left(3.0 \times 10^{-3} \mathrm{~mol} \mathrm{~L}^{-1}\right)$ and ionic strength $1.0 \mathrm{~mol} \mathrm{~L}^{-1},(\mathrm{NaCl})$ at $25.0 \pm 0.1{ }^{\circ} \mathrm{C}$. The catalytic activity of CDTA metal ion complexes of $\mathrm{Fe}(\mathrm{III}), \mathrm{Ni}(\mathrm{II}), \mathrm{Cu}(\mathrm{II}), \mathrm{Cr}(\mathrm{III})$ and $\mathrm{Mn}(\mathrm{II})$ was also examined. The pseudo-first-order rate constant was proportional to the concentration of $\mathrm{Fe}(\mathrm{III}) / \mathrm{CDTA}$, which is the best catalyst, in the range of (1-10) $\times 10^{-5} \mathrm{~mol} \mathrm{~L}^{-1}$.

Keywords: ascorbic acid, tris(oxalate)cobaltate(III), CDTA, iron(III), kinetic study

\section{Introduction}

The redox reactions of L-ascorbic acid are of fundamental interest in chemistry, biochemistry, pharmacology and several areas of medicine, since it is necessary in human diet in order to synthesize collagen and epinephrine, besides preventing scurvy. L-Ascorbic acid, $\mathrm{H}_{2} \mathrm{~A}$, has two acid protons $\left(\mathrm{pK}_{1}=4.04\right.$ and $\mathrm{pK}_{2}=$ 11.34), and is a strong reducing agent $\left(\mathrm{E}^{0} \mathrm{D} / \mathrm{H}_{2} \mathrm{~A}=0.390\right.$ $\mathrm{V} v s$. N.H.E.) in aqueous solution. This reduction potential depends on the medium acidity, and in some cases the $\mathrm{HA}^{-}, \mathrm{HA}^{\bullet}, \mathrm{A}^{-} \bullet$ radicals may be formed as intermediate species. ${ }^{1-4}$

Redox studies of L-ascorbic acid by various metal ion complexes have proposed the formation of a protonated ascorbate free radicals as $\mathrm{H}_{2} \mathrm{~A}^{+\bullet}$ or $\mathrm{HA}^{\bullet}$ but not the radical $\mathbf{A}^{-\bullet}$ in the rate-determining step. ${ }^{3-9}$

The oxidation studies of L-ascorbic acid by $\left[\mathrm{Co}\left(\mathrm{C}_{2} \mathrm{O}_{4}\right)_{3}\right]^{3-}$ were already performed in basic and acid

\footnotetext{
* e-mail: ncoichev@iq.usp.br
}

aqueous solutions, and it was pointed out that the redox process in acidic medium $(3.2<\mathrm{pH}<4.7)$ produced Ldehydroascorbic acid, D (equation 1). L-dehydroascorbic acid, D, also includes the hydration and cyclization of D form, with formation of the bicyclic-L-dehydro species. ${ }^{8,9}$ These studies indicated an outer-sphere electron-transfer process and no evidence of stable intermediate species formation.

$$
\mathrm{H}_{2} \mathrm{~A}+2\left[\mathrm{Co}^{\mathrm{II}}\left(\mathrm{C}_{2} \mathrm{O}_{4}\right)_{3}\right]^{3-} \longrightarrow \mathrm{D}+2 \mathrm{H}^{+}+2\left[\mathrm{Co}^{\mathrm{II}}\left(\mathrm{C}_{2} \mathrm{O}_{4}\right)_{3}\right]^{4-}
$$

The redox reaction rate demonstrates a strong dependency on the $\mathrm{pH}$ and the oxidation of $\mathrm{A}^{2-}$ showed to be faster than $\mathrm{HA}^{-}$or $\mathrm{H}_{2} \mathrm{~A}^{8,9}$

It was found that iron(III) catalyzes the oxidation of L-ascorbic acid by dissolved oxygen, hydrogen peroxide, peroxide-bound chromium and $\left[\mathrm{Co}\left(\mathrm{C}_{2} \mathrm{O}_{4}\right)_{3}\right]^{3-}$ in presence of EDTA. ${ }^{10-14}$ This last study, performed in universal buffer medium, led to a linear relationship between the observed pseudo-first order constant and the iron(III)/EDTA complex concentration. ${ }^{14}$ 
The catalytic effect of iron(III)/EDTA could be explained by the much faster reactions of iron(III)/ EDTA, rather than $\left[\mathrm{Co}\left(\mathrm{C}_{2} \mathrm{O}_{4}\right)_{3}\right]^{3-}$, with L-ascorbic acid. ${ }^{14}$ The rate constants for the reduction of several iron(III)/ complexes and $\left[\mathrm{Co}\left(\mathrm{C}_{2} \mathrm{O}_{4}\right)_{3}\right]^{3-}$ by L-ascorbic acid are reported in the literature and showed the strong influence of acidity and also the effect of the ligand, $\mathrm{L}$, coordinated to $\mathrm{Fe}(\mathrm{III})\left(\mathrm{L}=\mathrm{H}_{2} \mathrm{O}\right.$, phen, EDTA, bipy, $\left.\mathrm{C}_{2} \mathrm{O}_{4}{ }^{2-}\right)^{5,6,8-10,14-17}$

The reaction of $\mathrm{Fe}$ (II) with $\left[\mathrm{Co}\left(\mathrm{C}_{2} \mathrm{O}_{4}\right)_{3}\right]^{3-}$, which was investigated by some authors, has also to be considered. By keeping $\left[\mathrm{Co}\left(\mathrm{C}_{2} \mathrm{O}_{4}\right)_{3}\right]^{3-}$ at $5 \times 10^{-2} \mathrm{~mol} \mathrm{~L}^{-1}$, which is about ten times over iron(II) concentration, the $\mathrm{k}_{o b s}$ value obtained for the redox reaction was $9.49 \mathrm{~s}^{-1}$ and $\mathrm{k}=190 \mathrm{~mol}^{-1} \mathrm{~L} \mathrm{~s}^{-1} \cdot{ }^{18-20}$

In this work the catalytic effect of iron(III) on the oxidation of L-ascorbic acid by $\left[\mathrm{Co}\left(\mathrm{C}_{2} \mathrm{O}_{4}\right)_{3}\right]^{3-}$ was studied in the presence of polyaminocarboxylic acid, CDTA $\left(\mathrm{pK}_{1}=2.42 ; \mathrm{pK}_{2}=3.54 ; \mathrm{pK}_{3}=5.84\right.$ and $\mathrm{pK}_{4}=$ 9.22 ), in a universal buffer solution over a large $\mathrm{pH}$ region. This study provides information to improve an analytical method for iron(III) at $\mathrm{pH}=7.0 .^{14,17}$ For comparative studies, the catalytic effect of others transitions metal ions such as: $\mathrm{Ni}(\mathrm{II}), \mathrm{Cu}(\mathrm{II}), \mathrm{Cr}(\mathrm{III})$ and $\mathrm{Mn}$ (II) was also investigated.

\section{Experimental}

\section{Reagents and solutions}

All reagents used were from $\mathrm{AR}$ or $\mathrm{CP}$ specification and all solutions were prepared using deionised water obtained from a Nanopure System. Sodium chloride (Merck), stock solution $\left(2.0 \mathrm{~mol} \mathrm{~L}^{-1}\right)$, was prepared without further purification or standardization. Sodium hydroxide (Aldrich), $1.768 \mathrm{~mol} \mathrm{~L}^{-1}$ was standardized with potassium hydrogenphthalate. ${ }^{21}$

CDTA, trans-1,2-cyclohexyletilenedinitrilotetraacetic acid, $\mathrm{C}_{14} \mathrm{H}_{22} \mathrm{~N}_{2} \mathrm{O}_{8} \cdot \mathrm{H}_{2} \mathrm{O}$ (Merck), stock solution $\left(1.5 \times 10^{-2}\right.$ mol L ${ }^{-1}, \mathrm{pH}=5.8$ ) was prepared by dissolution in $\mathrm{NaOH}$ standard solution $(\mathrm{pH}=5.8)$.

Phosphoric, acetic and boric acids (Merck) $1.80 \mathrm{~mol}$ $\mathrm{L}^{-1}$ stock solutions were diluted to $0.180 \mathrm{~mol} \mathrm{~L}^{-1}$ and then standardized with $\mathrm{NaOH}$ solution $\left(0.1768 \mathrm{~mol} \mathrm{~L}^{-1}\right)$.

Iron(III) perchlorate (Aldrich) stock solution $\left(6.0 \times 10^{-2}\right.$ mol L ${ }^{-1}$ ) was standardized by complexometric method with EDTA. ${ }^{21}$ The potassium tris(oxalate) cobaltate(III) salt was prepared as described elsewhere. ${ }^{22}$ It was dissolved in buffer solution just before use in order to get a solution $6.0 \times 10^{-3}$ mol L-1. L-Ascorbic acid (Merck), $\mathrm{L}^{-\mathrm{C}_{6}} \mathrm{H}_{8} \mathrm{O}_{6}$, was also dissolved in buffer solution, just before use, in order to obtain a solution $6.0 \times 10^{-2} \mathrm{~mol} \mathrm{~L}^{-1}$.
Working solutions and spectrophotometric measurements

Several universal buffers solutions were prepared containing $\mathrm{H}_{3} \mathrm{PO}_{4}, \mathrm{H}_{3} \mathrm{C}-\mathrm{COOH}$ and $\mathrm{H}_{3} \mathrm{BO}_{3}\left(0.18 \mathrm{~mol} \mathrm{~L}^{-1}\right.$ of each). $\mathrm{NaOH} 1.768 \mathrm{~mol} \mathrm{~L}^{-1}$ standard solution was used to adjust the $\mathrm{pH}$ of the buffers solutions from 3 to $8 .{ }^{23}$ $\mathrm{NaCl} 2.0 \mathrm{~mol} \mathrm{~L}^{-1}$ solution was use to make up the ionic strength $1.0 \mathrm{~mol} \mathrm{~L}^{-1}$ in all working solutions.

The working solutions were prepared by mixing equal volumes of the of $\mathrm{L}_{-} \mathrm{C}_{6} \mathrm{H}_{8} \mathrm{O}_{6} 6.0 \times 10^{-2} \mathrm{~mol} \mathrm{~L}^{-1}$ and $\left[\mathrm{Co}\left(\mathrm{C}_{2} \mathrm{O}_{4}\right)_{3}\right]^{3-} 6.0 \times 10^{-3} \mathrm{~mol} \mathrm{~L}^{-1}$ solutions containing CDTA $6.0 \times 10^{-3} \mathrm{~mol} \mathrm{~L}^{-1}$. In the catalytic studies iron(III) was added as $\mathrm{Fe}(\mathrm{III}) / \mathrm{CDTA}$ in the $\mathrm{L}_{-} \mathrm{C}_{6} \mathrm{H}_{8} \mathrm{O}_{6}$ solution just before mixing, once $\mathrm{Fe}(\mathrm{III})$ is reduced by $\mathrm{L}_{-} \mathrm{C}_{6} \mathrm{H}_{8} \mathrm{O}_{6}$.

The final solutions concentration of $\left[\mathrm{Co}\left(\mathrm{C}_{2} \mathrm{O}_{4}\right)_{3}\right]^{3-}$, CDTA, $\mathrm{L}_{-} \mathrm{C}_{6} \mathrm{H}_{8} \mathrm{O}_{6}$ and $\mathrm{Fe}(\mathrm{III}) / \mathrm{CDTA}$, after mixture, were $3.0 \times 10^{-3}, 3.0 \times 10^{-3}, 3.0 \times 10^{-2}$ and $(1-10) \times 10^{-5} \mathrm{~mol} \mathrm{~L}^{-1}$, respectively.

A glass electrode, combined with an $\mathrm{Ag} / \mathrm{AgCl}$ reference electrode, Metrohm AG Herisau, filled with 3.0 mol L ${ }^{-1} \mathrm{NaCl}$ and a $654 \mathrm{pHMeter}$ Metrohm instrument were used in the $\mathrm{pH}$ measurements at $(25.0 \pm 0.1){ }^{\circ} \mathrm{C}$.

Spectrophotometric measurements were performed in a Hewlett Packard 8452A diode-array spectrophotometer using a thermostated Tanden cell (optical path length $=0.875 \mathrm{~cm}$ ).

\section{Results and Discussion}

\section{Data treatment}

The redox reaction was followed spectrophotometrically at $600 \mathrm{~nm}$ where the major absorbing species is the complex $\left[\mathrm{Co}\left(\mathrm{C}_{2} \mathrm{O}_{4}\right)_{3}\right]^{3-}$ (molar absorptivity of $150 \pm$ $\left.10 \mathrm{~mol}^{-1} \mathrm{~L} \mathrm{~cm}^{-1}\right){ }^{14}$

A ten times excess of $\mathrm{L}_{-} \mathrm{C}_{6} \mathrm{H}_{8} \mathrm{O}_{6}$ over $\left[\mathrm{Co}\left(\mathrm{C}_{2} \mathrm{O}_{4}\right)_{3}\right]^{3-}$ was kept in all experiments in order to have pseudo first order conditions. As the reaction was not affected by dissolved oxygen it was not necessary to eliminate the dissolved air before the kinetic runs.

The kinetic curves were analysed with the OLIS KINFIT set of programs. All the observed rate constants values presented in this work are the mean of at least three determinations and have an average error smaller than $5 \% .^{24}$

\section{The $p H$ influence on the uncatalysed reaction}

The variation of $\left[\mathrm{Co}\left(\mathrm{C}_{2} \mathrm{O}_{4}\right)_{3}\right]^{3-}$ concentration with time from the reduction by $\mathrm{L}_{-} \mathrm{C}_{6} \mathrm{H}_{8} \mathrm{O}_{6}$, in the absence of any CDTA metal ion complexes showed a pseudo-first-order behaviour. 
These experiments were carried out over a large $\mathrm{pH}$ range in universal buffer solution containing CDTA, which was added to avoid precipitation of cobalt(II) and cobalt(III) oxalate at high $\mathrm{pH}$. No experiments at $\mathrm{pH}$ lower than 3.0 were carried out, due to the $\left[\mathrm{Co}\left(\mathrm{C}_{2} \mathrm{O}_{4}\right)_{3}\right]^{3-}$ decomposition and precipitation of CDTA. ${ }^{25,26}$

The dependence of $\mathrm{k}_{o b s}$ with $\mathrm{pH}$ (Figure 1) suggests that the $\mathrm{H}_{2} \mathrm{~A}$ specie is much less reactive than the $\mathrm{HA}^{-}$ species. In the $6.0<\mathrm{pH}<7.5$ range, where $\mathrm{HA}^{-}$is the predominant species, the $\mathrm{k}_{\text {obs }}$ value is almost constant. It was observed that at $\mathrm{pH}$ higher than 10 the oxidised species, D, decomposes rapidly. ${ }^{1,4,14}$

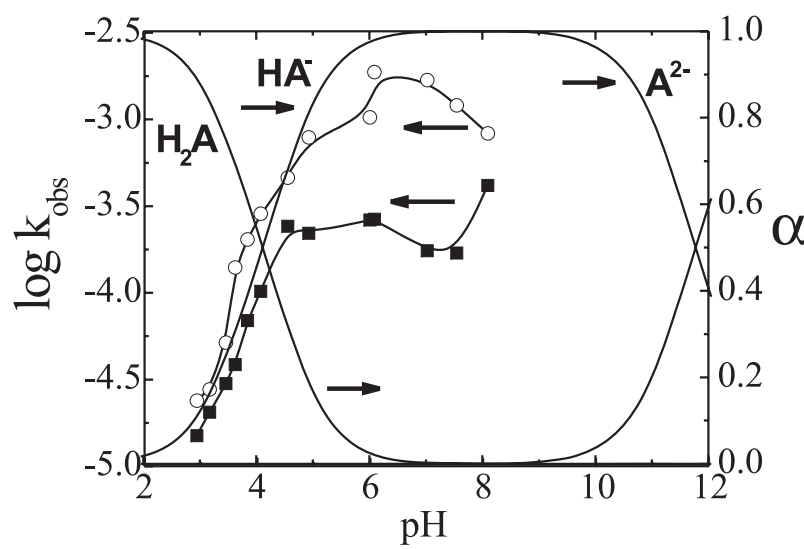

Figure 1. The diagram distribution $(\alpha v s$. $\mathrm{pH})$ for $\mathrm{L}-\mathrm{C}_{6} \mathrm{H}_{8} \mathrm{O}_{6}$ and the variation of $\mathrm{k}_{o b s}$ in function of acidity $\left(\log \mathrm{k}_{o b s} v s . \mathrm{pH}\right)$ for redox reaction between $\mathrm{L}-\mathrm{C}_{6} \mathrm{H}_{8} \mathrm{O}_{6}$ and $\left[\mathrm{Co}\left(\mathrm{C}_{2} \mathrm{O}_{4}\right)_{3}\right]^{3-}$ without $(\mathbf{\square})$ and with $[\mathrm{Fe}(\mathrm{III}) / \mathrm{CDTA}]$ $=1.0 \times 10^{-5} \mathrm{~mol} \mathrm{~L}^{-1}$ as catalyst $(\mathrm{O}) .\left[\mathrm{L}-\mathrm{C}_{6} \mathrm{H}_{8} \mathrm{O}_{6}\right]=3.0 \times 10^{-2} \mathrm{~mol} \mathrm{~L}^{-1}$. $\left[\mathrm{Co}\left(\mathrm{C}_{2} \mathrm{O}_{4}\right)_{3}\right]^{3-}=3.0 \times 10^{-3} \mathrm{~mol} \mathrm{~L}^{-1} ;$ [CDTA $]=3.0 \times 10^{-3} \mathrm{~mol} \mathrm{~L}^{-1}$; ionic strength $=1.0 \mathrm{~mol} \mathrm{~L}^{-1} \mathrm{kept}$ with $\mathrm{NaCl}$ in universal buffer $(25.0 \pm 0.1)^{\circ} \mathrm{C}$.

The sequence of reactions represented below, may describe the mechanism. ${ }^{8,9,14}$

$$
\begin{array}{ll}
\mathrm{H}_{2} \mathrm{~A} \rightleftharpoons \mathrm{HA}^{-}+\mathrm{H}^{+} & \mathrm{pK}_{1}=4.04 \\
\mathrm{HA}^{-} \rightleftharpoons \mathrm{A}^{2-}+\mathrm{H}^{+} & \mathrm{pK}_{2}=11.34
\end{array}
$$

$\mathrm{H}_{2} \mathrm{~A}+\left[\mathrm{Co}\left(\mathrm{C}_{2} \mathrm{O}_{4}\right)_{3}\right]^{3-} \longrightarrow \mathrm{H}_{2} \mathrm{~A}^{+\bullet}+\mathrm{Co}^{2+}+3 \mathrm{C}_{2} \mathrm{O}_{4}^{2-} \mathrm{ka}$

$\mathrm{HA}^{-}+\left[\mathrm{Co}\left(\mathrm{C}_{2} \mathrm{O}_{4}\right)_{3}\right]^{3-} \longrightarrow \mathrm{HA} \bullet+\mathrm{Co}^{2+}+3 \mathrm{C}_{2} \mathrm{O}_{4}^{2-} \quad \mathrm{kb}$

$$
\mathrm{A}^{2-}+\left[\mathrm{Co}\left(\mathrm{C}_{2} \mathrm{O}_{4}\right)_{3}\right]^{3-} \longrightarrow \mathrm{A}^{-\bullet}+\left[\mathrm{Co}\left(\mathrm{C}_{2} \mathrm{O}_{4}\right)_{3}\right]^{4-} \quad \mathrm{kc}
$$

$$
\mathrm{H}_{2} \mathrm{~A}^{+\bullet} / \mathrm{HA} / \mathrm{A}^{\bullet}+\left[\mathrm{Co}\left(\mathrm{C}_{2} \mathrm{O}_{4}\right)_{3}\right]^{3-} \longrightarrow \mathrm{D}+\left[\mathrm{Co}\left(\mathrm{C}_{2} \mathrm{O}_{4}\right)_{3}\right]^{4-}+2 \mathrm{H}^{+}
$$

The reduction rate of the tris(oxalate)cobaltate(III) complex concentration is given by the rate law described in equation 8. Using the experimental data obtained at $\mathrm{pH}$ range from 3 to 5 the rate law under pseudo-first-order conditions can be written by equation 9 , which results in equation 10 (in all equations $\mathrm{C}_{\mathrm{H}_{2} \mathrm{~A}}$ is the total concentration of ascorbic acid).

$\frac{\mathrm{d}\left[\mathrm{Co}\left(\mathrm{C}_{2} \mathrm{O}_{4}\right)_{3}^{3-}\right]}{\mathrm{dt}}=2\left\{\mathrm{k}_{\mathrm{a}}\left[\mathrm{H}_{2} \mathrm{~A}\right]+\mathrm{k}_{\mathrm{b}}\left[\mathrm{HA}^{-}\right]+\mathrm{k}_{\mathrm{c}}\left[\mathrm{A}^{2-}\right]\right\}\left[\mathrm{Co}\left(\mathrm{C}_{2} \mathrm{O}_{4}\right)_{3}^{3-}\right]$

In this $\mathrm{pH}$ range the contribution $\mathrm{A}^{2-}$ is very small (see Figure 1) and the term $\mathrm{k}_{\mathrm{c}}\left[\mathrm{A}^{2-}\right]$ can be ignored.

$$
\begin{aligned}
& \frac{\mathrm{d}\left[\mathrm{Co}\left(\mathrm{C}_{2} \mathrm{O}_{4}\right)_{3}^{3-}\right]}{\mathrm{dt}}=2\left\{\frac{\mathrm{k}_{\mathrm{a}}\left[\mathrm{H}^{+}\right]+\mathrm{k}_{\mathrm{b}} \mathrm{K}_{1}}{\left[\mathrm{H}^{+}\right]+\mathrm{K}_{1}}\right\} \mathrm{C}_{\mathrm{H}_{2} \mathrm{~A}}\left[\mathrm{Co}\left(\mathrm{C}_{2} \mathrm{O}_{4}\right)_{3}^{3-}\right] \\
& \mathrm{k}_{\mathrm{obs}}=\frac{2 \mathrm{k}_{\mathrm{a}}\left[\mathrm{H}^{+}\right]+2 \mathrm{k}_{\mathrm{b}} \mathrm{K}_{1}}{\left[\mathrm{H}^{+}\right]+\mathrm{K}_{1}} \cdot \mathrm{C}_{\mathrm{H}_{2} \mathrm{~A}}
\end{aligned}
$$

By working under limiting conditions, such as $\mathrm{k}_{a}$ is much smaller than $\mathrm{k}_{b}$ because $\mathrm{H}_{2} \mathrm{~A}$ (equation 4) reacts much slower than $\mathrm{HA}^{-}$(equation 5), the term $2 \mathrm{k}_{\mathrm{a}}\left[\mathrm{H}^{+}\right]$can be neglected and the equation 10 can be represented as equation 11 , as follows:

$\frac{1}{\mathrm{k}_{\mathrm{obs}}}=\frac{\left[\mathrm{H}^{+}\right]}{2 \mathrm{k}_{\mathrm{b}} \mathrm{K}_{1} \mathrm{C}_{\mathrm{H}_{2} \mathrm{~A}}}+\frac{1}{2 \mathrm{k}_{\mathrm{b}} \mathrm{C}_{\mathrm{H}_{2}} \mathrm{~A}}$

Taking the equation 11 , in the $\mathrm{pH}$ region from 3 to 5 , a plot of $1 / \mathrm{k}_{o b s} v s .\left[\mathrm{H}^{+}\right]$provides a linear relationship and from the slope and intercept the values of $\mathrm{k}_{b}$ and $\mathrm{K}_{1}$ can be, respectively, obtained (Figure 2). The least squares regression $\left(Y=5465+6.382 \times 10^{6} \mathrm{X}, \mathrm{r}=0.97\right)$ showed some dispersion of the experimental data in spite of the $\mathrm{k}_{o b s}$ values have been obtained with the average error smaller than $5 \%$. The values found were $\mathrm{k}_{\mathrm{b}}=(3.2 \pm 1.5) \times 10^{-3} \mathrm{~mol}^{-1} \mathrm{~L} \mathrm{~s}^{-1}$ and $\mathrm{K}_{1}=(0.83 \pm 0.09) \times 10^{-4} \mathrm{~mol} \mathrm{~L}^{-1}$ and the order of magnitude of these data is in good agreement with the literature: $\mathrm{k}_{\mathrm{b}}=$ $4.1 \times 10^{-3} \mathrm{~mol}^{-1} \mathrm{~L} \mathrm{~s}^{-1}, \mathrm{~K}_{1}=1.12 \times 10^{-4} \mathrm{~mol} \mathrm{~L}^{-1}, \mathrm{k}_{b}=7.0 \times 10^{-3}$ $\mathrm{mol}^{-1} \mathrm{~L} \mathrm{~s}^{-1}$ and $\mathrm{K}_{1}=0.71 \times 10^{-4} \mathrm{~mol} \mathrm{~L}^{-1} .,{ }^{9} 14$

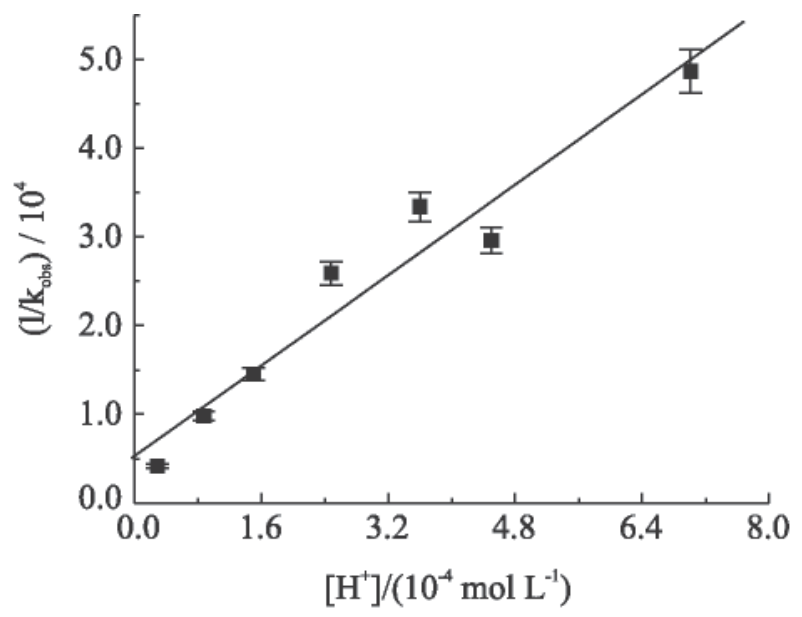

Figure 2. Determination of $\mathrm{k}_{\mathrm{b}}$ considering the equation (11). $\mathrm{K}_{1}$ and the $\mathrm{k}_{\text {obs }}$ calculated in the range of $\mathrm{pH} 3-5$. 
By using the experimental data, which were obtained in the $\mathrm{pH}$ range from 6.0 to 8.0 , the rate law can be described according to the following equations:

$\frac{\mathrm{d}\left[\mathrm{Co}\left(\mathrm{C}_{2} \mathrm{O}_{4}\right)_{3}^{3-}\right]}{\mathrm{dt}}=2 \mathrm{k}_{\mathrm{c}}\left[\mathrm{A}^{2-}\right]\left[\mathrm{Co}\left(\mathrm{C}_{2} \mathrm{O}_{4}\right)_{3}^{3-}\right]=2 \mathrm{k}_{\mathrm{c}} \frac{\mathrm{K}_{2} \cdot \mathrm{C}_{\mathrm{H}_{2} \mathrm{~A}}}{\left[\mathrm{H}^{+}\right]}\left[\mathrm{Co}\left(\mathrm{C}_{2} \mathrm{O}_{4}\right)_{3}^{3-}\right]$

$\mathrm{k}_{\mathrm{obs}}=2 \mathrm{k}_{\mathrm{c}} \frac{\mathrm{K}_{2} \mathrm{C}_{\mathrm{H}_{2} \mathrm{~A}}}{\left[\mathrm{H}^{+}\right]}$

Taking into account the second ionisation step for ascorbic acid $\mathrm{K}_{2}=4.6 \times 10^{-12} \mathrm{~mol} \mathrm{~L}^{-1}$, the $\mathrm{k}_{c}=8.5 \mathrm{~mol}^{-1} \mathrm{~L}$ $\mathrm{s}^{-1}$ was obtained from the slope of the $\mathrm{k}_{\text {obs }}$ vs. $1 /\left[\mathrm{H}^{+}\right]$plot. The $\mathrm{k}_{c}$ values found in the literature were $20 \mathrm{~mol}^{-1} \mathrm{~L} \mathrm{~s}^{-1}$ and $10.8 \mathrm{~mol}^{-1} \mathrm{~L} \mathrm{~s}^{-1}$, in universal buffer solution and in ionic strength kept with $\mathrm{NaClO}_{4}$ and $\mathrm{NaCl}$, respectively. ${ }^{8,14,23}$

\section{The iron(III) catalytic effect}

The variation of the $\left[\mathrm{Co}\left(\mathrm{C}_{2} \mathrm{O}_{4}\right)_{3}\right]^{3-}$ concentration by the reduction with $\mathrm{L}_{-} \mathrm{C}_{6} \mathrm{H}_{8} \mathrm{O}_{6}$, in the presence of $\mathrm{Fe}(\mathrm{III}) /$ CDTA complex, also revealed a pseudo-first-order rate behaviour. The observed rate constant is proportional to the $\mathrm{Fe}(\mathrm{III})$ concentration and dependent of the $\mathrm{pH}$ medium (Figures 1 and 3).

It can be also noted that at $\mathrm{pH}$ lower than 5.0, where $\mathrm{H}_{2} \mathrm{~A}$ and $\mathrm{HA}^{-}$species are present, the reaction is slower even in the presence of $\mathrm{Fe}(\mathrm{III})$.

The $\mathrm{k}_{o b s}$ values depend linearly on the iron concentration (Figure 3). According to equation 14, where the intercept, $\mathrm{k}_{u n c}$, is $\mathrm{k}_{o b s}$ for the uncatalysed reaction and the slope, $\mathrm{k}_{s p e}$, is the specific rate constant for iron(III)

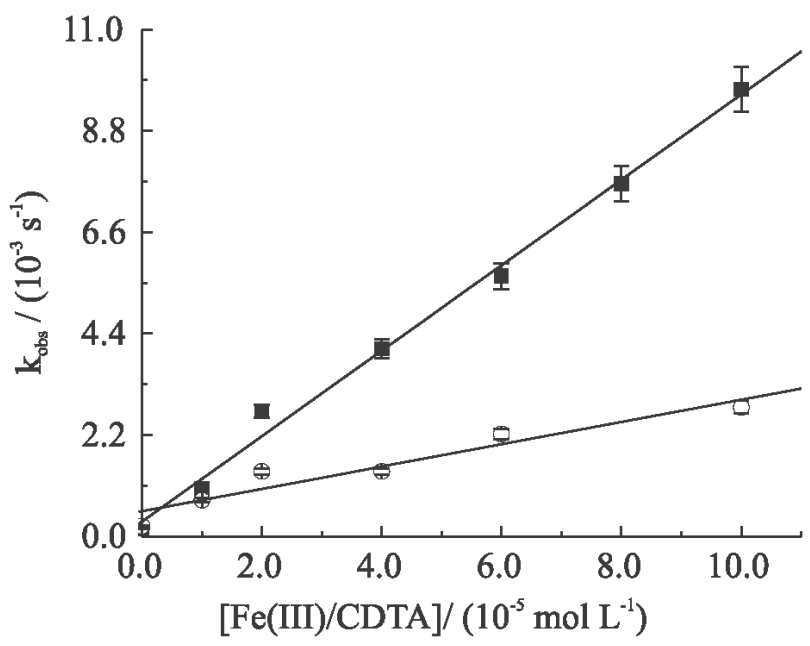

Figure 3. Influence of iron(III) concentration on the $\mathrm{k}_{\text {obs }}$ values. [ $\mathrm{L}$ $\left.\mathrm{C}_{6} \mathrm{H}_{8} \mathrm{O}_{6}\right]=3.0 \times 10^{-2} \mathrm{~mol} \mathrm{~L}^{-1} ;\left[\mathrm{Co}\left(\mathrm{C}_{2} \mathrm{O}_{4}\right)_{3}\right]^{3-}=3.0 \times 10^{-3} \mathrm{~mol} \mathrm{~L}^{-1}$; [CDTA $]=$ $3.0 \times 10^{-3} \mathrm{~mol} \mathrm{~L}^{-1}$; ionic strength $=1.0 \mathrm{~mol} \mathrm{~L}^{-1} \mathrm{kept}$ with $\mathrm{NaCl}$ in universal buffer $(25.0 \pm 0.1)^{\circ} \mathrm{C}$. $(\mathbf{\square})=\mathrm{pH} 7.5$ and $(\mathrm{O})=\mathrm{pH} 5.0$. catalysed reaction. At $\mathrm{pH}=5.0$ it was obtained $\mathrm{k}_{\text {unc }}$. $=$ $2.2 \times 10^{-4} \mathrm{~s}^{-1}$ and $\mathrm{k}_{\text {spe }}=24 \mathrm{~mol}^{-1} \mathrm{~L} \mathrm{~s}^{-1}$ but at $\mathrm{pH}=7.5, \mathrm{k}_{\text {unc }}$ and $\mathrm{k}_{\text {spe }}$ were found to be $3.2 \times 10^{-4} \mathrm{~s}^{-1}$ and $93 \mathrm{~mol}^{-1} \mathrm{~L} \mathrm{~s}^{-1}$, respectively (Figure 3 ). In similar studies with $\mathrm{Fe}(\mathrm{III}) /$ EDTA, at $\mathrm{pH} 7.0$, it was obtained $\mathrm{k}_{\text {spe }}=145 \mathrm{~mol}^{-1} \mathrm{~L} \mathrm{~s}^{-1}$ and the $\mathrm{k}_{\text {obs }}$ and $\mathrm{k}_{\text {spe }}$ had maximum values, where $\mathrm{HA}^{-}$is the predominant species in solution. ${ }^{14}$

$\mathrm{k}_{\text {obs }}=\mathrm{k}_{u n c}+\mathrm{k}_{\text {spe }}[\mathrm{Fe}(\mathrm{III})]$

Likewise $\mathrm{Fe}(\mathrm{III}) / \mathrm{EDTA}$, when $\mathrm{Fe}(\mathrm{III}) / \mathrm{CDTA}$ is acting as a catalyst, the mechanism can be described by the sequence of reactions from 15 to 19 , where the electron transfer reaction involving $\mathrm{Fe}(\mathrm{II})$ is much faster than the reaction of $\mathrm{Co}$ (III) complex with ascorbic acid, as it was described in the literature. ${ }^{5,6,9,14-17}$

$$
\begin{aligned}
& \mathrm{Fe}(\mathrm{III}) /(\mathrm{CDTA})+\mathrm{HA}^{-} \longrightarrow \mathrm{Fe}(\mathrm{III}) /(\mathrm{CDTA})(\mathrm{HA})^{-} \\
& \mathrm{Fe}(\mathrm{III}) /(\mathrm{CDTA})(\mathrm{HA})^{-} \longrightarrow \mathrm{Fe}(\mathrm{II}) /(\mathrm{CDTA})+\mathrm{HA}^{\bullet}
\end{aligned}
$$

$\mathrm{Fe}(\mathrm{II}) /(\mathrm{CDTA})+\left[\mathrm{Co}\left(\mathrm{C}_{2} \mathrm{O}_{4}\right)_{3}\right]^{3-} \underset{\mathrm{Co}^{2+}+3 \mathrm{C}_{2} \mathrm{O}_{4}^{2-} \quad(17)}{\longrightarrow} \mathrm{Fe}(\mathrm{III}) /(\mathrm{CDTA})+$

$\mathrm{HA}^{\bullet}+\left[\mathrm{Co}\left(\mathrm{C}_{2} \mathrm{O}_{4}\right)_{3}\right]^{3-} \longrightarrow \mathrm{D}+\mathrm{Co}^{2+}+3 \mathrm{C}_{2} \mathrm{O}_{4}^{2-}$

$\mathrm{Fe}(\mathrm{III}) /(\mathrm{CDTA})+\mathrm{HA}^{\bullet} \longrightarrow \mathrm{Fe}(\mathrm{II}) / \mathrm{CDTA}+\mathrm{D}+\mathrm{H}^{+}$

The catalytic effect of Fe(III)/CDTA $(\log \beta=30.1$, $\left.\mathrm{k}_{\text {spe }}=93 \mathrm{~mol}^{-1} \mathrm{~L} \mathrm{~s}^{-1}, \mathrm{pH}=7.5\right)$ is smaller than $\mathrm{Fe}(\mathrm{III}) /$ EDTA $\left(\log \beta=23.8, \mathrm{k}_{\text {spe }}=145 \mathrm{~mol}^{-1} \mathrm{~L} \mathrm{~s}^{-1}, \mathrm{pH}=7.5\right){ }^{14,27}$ The Fe(III)/EDTA complex, which is seven coordinated with one coordination site occupied by a labile water molecule, will account for the efficient formation of a inner-sphere complex, represented by equation $15 .^{10,28}$ The catalyst activities order for $\mathrm{Fe}(\mathrm{III}) / \mathrm{L}\left(\mathrm{L}=\right.$ phen, bipy, $\mathrm{H}_{2} \mathrm{O}$, EDTA, CDTA) reaction with $\mathrm{L}-\mathrm{C}_{6} \mathrm{H}_{8} \mathrm{O}_{6}$ depends on the nature of ligand and is in agreement with the reduction potential values for the complexes involved. .,69, 14-17 $^{5}$

\section{Influence of others transition metal ions}

The catalytic effects of other CDTA metal ion complexes were also investigated. At $\mathrm{pH}=7.5$ (Universal buffer) the observed rate constant was $1.7 \times 10^{-4} \mathrm{~s}^{-1}$ without catalyst $\left(\left[\mathrm{Co}\left(\mathrm{C}_{2} \mathrm{O}_{4}\right)_{3}\right]^{3-}\right.$, CDTA and $\mathrm{L}-\mathrm{C}_{6} \mathrm{H}_{8} \mathrm{O}_{6}$ were $3.0 \times 10^{-3}, 3.0 \times 10^{-3}$ and $3.0 \times 10^{-2} \mathrm{~mol} \mathrm{~L}^{-1}$, respectively). $\mathrm{Cu}(\mathrm{II}) / \mathrm{CDTA}\left(\mathrm{k}_{o b s}=2.3 \times 10^{-4} \mathrm{~s}^{-1}\right), \mathrm{Mn}(\mathrm{II}) / \mathrm{CDTA}\left(\mathrm{k}_{o b s}=\right.$ $\left.2.4 \times 10^{-4} \mathrm{~s}^{-1}\right)$ and $\mathrm{Ni}(\mathrm{II}) / \mathrm{CDTA}\left(\mathrm{k}_{\text {obs }}=2.4 \times 10^{-4} \mathrm{~s}^{-1}\right)$ exhibit no significant catalytic effect. Cr(III)/CDTA showed some activity $\left(\mathrm{k}_{\text {obs }}=3.8 \times 10^{-4} \mathrm{~s}^{-1}\right)$ but ten times lower than the 
$\mathrm{Fe}(\mathrm{III}) / \mathrm{CDTA}\left(\mathrm{k}_{\text {obs }}=3.9 \times 10^{-3} \mathrm{~s}^{-1}\right)$. For Cr(III)/CDTA it can be assume that $\mathrm{Cr}(\mathrm{III})$ is present as free ion due to the inertia in the $\mathrm{Cr}$ (III) complexes formation.

\section{Conclusions}

The reduction of iron(III) complexes and tris(oxalate) cobaltate by L-ascorbic acid depends on the $\mathrm{pH}$ and the nature of the ligand. Iron(III) complexes react much faster than $\left[\mathrm{Co}\left(\mathrm{C}_{2} \mathrm{O}_{4}\right)_{3}\right]^{3-}$, which may explain the catalytic effect of iron(III) ion. Considering the dependence of $\mathrm{k}_{\mathrm{obs}}$ with the $\mathrm{pH}$, it was possible to calculate the rate constants of the reaction involving the species $\mathrm{H}_{2} \mathrm{~A}, \mathrm{HA}^{-}$and $\mathrm{A}^{2-}$ (equations 4-6), the order of reactivity was $\mathrm{H}_{2} \mathrm{~A}<\mathrm{HA}^{-}<$ $\mathrm{A}^{2-}$. The present studies showed that $\mathrm{Fe}(\mathrm{III}) / \mathrm{CDTA}$ increases the catalytic activity of iron(III). As suggested by the literature,,$^{1-3}$ the addition of EDTA or CDTA to complex metal ions and stabilize ascorbic acid solutions from oxidation by oxygen may not work properly.

\section{Acknowledgments}

The authors acknowledge the financial support from Brazilian agencies: FAPESP (Fundação de Amparo à Pesquisa do Estado de São Paulo), CNPq (Conselho Nacional de Desenvolvimento Científico e Tecnológico) and NEPAS (Núcleo de Ensino, Pesquisa e Assessoria a Saúde da FMABC).

\section{Supplementary Information}

Supplementary data are available free of charge as PDF file at http://jbcs.sbq.org.br.

\section{References}

1. Tur'yan, Y.; Kohen, R.; J. Electroanal. Chem. 1995, 380, 273.

2. Roig, M.G.; Rivera, Z.S.; Kennedy, J.F.; Int. J. Food Sci. Nutr. 1993, 44, 59.

3. Davies, M.D.; Polyhedron 1992, 11, 285 and references therein.

4. Willians, N.H.; Yandell, J.K.; Aust. J. Chem. 1982, 35, 1133.

5. Bänsch, B.; Martinez, P.; Uribe, D.; Zuluaga, J.; van Eldik, R.; Inorg. Chem. 1991, 30, 4555.

6. Bänsch, B.; van Eldik, R.; Martinez, P.; Inorg. Chim. Acta 1992, 201, 75 .
7. Martinez, P.; Zuluaga, J.; Uribe, D.; van Eldik, R.; Inorg. Chim. Acta 1987, 136, 11.

8. Martinez, P.; Zuluaga, J.; Kraft, J.; van Eldik, R.; Inorg. Chim. Acta 1988, 146, 9.

9. Kimura, M.; Yamamoto, M.; Yamabe, S.; J. Chem. Soc. Dalton Trans. 1982, 2, 423.

10. Taqui Khan, M.M.; Martell, A.E.; J. Am. Chem. Soc. 1967, 89, 4176.

11. Taqui Khan, M.M.; Martell, A.E.; J. Am. Chem. Soc. 1967, 89, 7104.

12. Grinstead, R.R.; J. Am. Chem. Soc. 1960, 82, 3464.

13. Ghosh, S.K.; Gould, E.S.; Inorg. Chem. 1989, 28, 1538.

14. Fornaro, A.; Coichev, N.; J. Coord. Chem. 1999, 46, 519.

15. Subba Rao, P.V.; Saradamba, G.V.; Ramakrishna, K.; Mohana Rao, K; Subbaiah, K.V.; Indian J. Chem. 1989, 28A, 1060.

16. Pelizzetti, E.; Mentasti, E.; Pramauro, E.; Inorg. Chem. 1978, 17, 1181.

17. Ohashi, K; Sagawa, T; Goto, E; Yamamoto, K.; Anal. Chim. Acta 1977, 92, 209.

18. Barrett, J.; Baxendale, J.H.; Transactions of the Faraday Society 1956, 52, 210.

19. Haim A.; Sutin, N.; J. Am. Chem. Soc. 1966, 88, 5343.

20. Cannon, R.D.; Stillman, J.S.; J. Chem. Soc., Dalton Trans. 1976, $5,428$.

21. Skoog, D.A.; West, D.M.; Holler, F. J.; Fundamentals of Analytical Chemistry, $7^{\text {th }}$ ed., Saunders College Publishing: Orlando, 1996, p. 870.

22. Booth, H. S.; Inorganic Synthesis, $1^{\text {st }}$ ed., McGraw-Hill Book Company: New York, 1939, Vol. I, p. 36.

23. Lurie, L.; Handbook of Analytical Chemistry, $2^{\text {nd }}$ ed., Mir: Moscow, 1975, p. 488.

24. Olis Kinfit Routines, On-Line Instruments Systems, Inc. Jefferson: GA, 1989.

25. Hin-Fat, L.; Higginson, W.C.E.; J. Chem. Soc. (A) 1970, 2836.

26. Aggett, J.; Odell, A.L.; J. Chem. Soc. (A) 1968, 1415.

27. Beck, M. T.; Gorog, S.; Journal of Inorganic \& Nuclear Chemistry 1960, 12, 353.

28. Dellert-Ritter, M.; van Eldik, R.; J. Chem Soc., Dalton Trans. 1992, 1037 and references therein.

Received: July 1, 2005

Published on the web: February 22, 2006

FAPESP helped in meeting the publication costs of this article. 